\title{
OFFICIAL STATISTICS UNTUK PEMODELAN INDEKS PENDIDIKAN MELALUI ANALISIS REGRESI DATA PANEL
}

\author{
Studi Kasus untuk Wilayah Kota dan Kabupaten di Jawa Barat
}

\author{
(Official Statistics for Education Index Modeling Through Panel Data Regression Analysis)
}

\author{
Meicheil Yohansa \\ Institut Pertanian Bogor \\ Jl. Raya Dramaga, Kampus IPB, Dramaga, Bogor, Jawa Barat, Indonesia - 16680 \\ meicheilyohansa@apps.ipb.ac.id
}

\begin{abstract}
ABSTRAK
Indonesia sebagai negara bekembang tengah banyak melakukan berbagai upaya pembangunan di berbagai sektor untuk menaikan indeks-indeks yang digunakan sebagai ukuran suatu negara maju. Bukan tanpa hasil, belakangan Indonesia dianggap sebagai salah satu negara yang memiliki perekonomian yang stabil di tengah kondisi ketidakpastian ekonomi secara global. Namun, ukuran suatu negara maju tidak hanya diukur melalui kondisi ekonomi, tetapi juga mencakup sektor kesehatan dan pendidikan. Hal ini yang kadang dipandang sebagai kondisi dilematis bagi pemerintah. Di satu sisi, pemerintah gencar dalam pemerataan pendapatan melalui pembangunan infrastruktur. Di sisi lain, hal-hal yang menyangkut kesejahteraan rakyat cenderung tidak menjadi prioritas. Misalkan di sektor pendidikan yang merupakan salah satu pilar pembangun negeri. Indeks pendidikan tertinggi diraih oleh provinsi DKI Jakarta sebagai ibukota negara. Sementara ketimpangan sangat terlihat untuk wilayah-wilayah lain, bahkan untuk wilayahwilayah yang masih bertetangga dengan DKI Jakarta. Di Jawa Barat misalnya. Beberapa wilayah di Jawa Barat masih berdekatan dengan DKI Jakarta, seperti Bekasi, Depok, dan Bogor. Namun nyatanya indeks pendidikan di Jawa Barat masih tertinggal cukup jauh dengan DKI Jakarta. Untuk itu, studi ini bertujuan untuk membandingkan faktor-faktor yang memengaruhi indeks pendidikan di Jawa Barat yang dibagi ke dalam wilayah kota dan kabupaten menggunakan analisis regresi data panel. Peubah penjelas yang digunakan adalah indeks keparahan kemiskinan, jumlah penduduk miskin, laju pertumbuhan penduduk, dan angka harapan hidup masing-masing untuk tahun 2011 hingga 2018. Hasilnya menunjukkan model pengaruh tetap dengan efek waktu adalah model terbaik untuk menggambarkan indeks pendidikan di wilayah kota maupun kabupaten denga $\mathrm{R}^{2}$ masing-masing sebesar $93,2 \%$ dan $37,9 \%$.
\end{abstract}

Kata kunci: Indeks Pembangunan Manusia, Indeks Pendidikan, Regresi Data Panel

\section{ABSTRACT}

Indonesia as a developing country is doing a lot of various development efforts in many sectors to raise the indices that used to measure a country into a developed country. Not without results, lately, Indonesia is considered as one of the countries that have a stable economy amid conditions of global economic uncertainty. However, the size of a developed country is not only measured through economic conditions but also includes the health and education sectors. This is sometimes seen as a dilemma for the government. On the one hand, the government is aggressively in the distribution of income through infrastructure development. On the other hand, matters relating to people's welfare tend not to be a priority. For example in the education sector which is one of the pillars of the country's development. The highest education index was achieved by DKI Jakarta province as the nation's capital. While inequality is very visible for other regions, even for areas that are still neighbors to DKI Jakarta. In West Java for example. Some areas in West Java are still close to DKI Jakarta, such as Bekasi, Depok, and Bogor. But in fact, the education index in West Java still lags far enough with DKI Jakarta. For this reason, this study aims to compare the factors that influence the education index in West Java, which is divided into cities and districts using panel data regression analysis. The explanatory variables used are the poverty severity index, the number of poor population, population growth rate, and life expectancy respectively for 2011 to 2018. The results show a fixed influence model with a time effect is the best model to describe the education index in urban and district areas with $R 2$ respectively $93.2 \%$ and $37.9 \%$.

Keywords: Human Development Index, Education index, West Java, Panel Data Regression 


\section{PENDAHULUAN}

Menuju negara maju menjadi salah satu fokus pemerintah dalam menata regulasi pemerintahan pada beberapa tahun terakhir. Berbagai strategi diupayakan pemerintah pusat yang kemudian diteruskan kepada pemerintah daerah untuk meningkatkan sektor-sektor strategis dalam pembangunan. Berbagai pro dan kontra kerap kali terjadi ketika pemerintah belakangan pada akhirnya banyak memfokuskan pada pembangunan infrastruktur. Pembangunan infrastruktur dianggap sebagai salah satu upaya percepatan pemerataan pembangunan hingga ke pelosok Indonesia. Kendati demikian, banyak pihak beranggapan sebaliknya, bahwa membangun manusia jauh lebih penting dibandingkan dengan upaya pembangunan infrastruktur yang bersifat fisik.

Terlepas dari berbagai opini mengenai prioritas pembangunan di Indonesia, perlu dipahami bahwa baik upaya pembangunan infrastruktur maupun pembangunan kualitas manusia keduanya menjadi komponen kriteria negara maju. Pembangunan infrastruktur yang sedang gencar dikerjakan pemerintah erat kaitannya dengan pertumbuhan ekonomi dan pemerataan pembangunan. Sementara indikator lainnya menyangkut indeks pembangunan manusia diukur melalui tiga komponen utama, yakni pendidikan, kesehatan, dan pendapatan (Setiawan \& Hakim, 2008). Kedua komponen sebagai indikator suatu negara maju tersebut bukanlah hal yang terpisah. Pertumbuhan ekonomi serta pemerataan pembangunan tentunya akan menunjang kualitas pendidikan, kesehatan, dan pemerataan pendapatan hingga ke daerah.

Upaya-upaya pemerintah dalam kegencarannya melakukan pembangunan bersifat fisik banyak menuai pujian dan pengakuan. Pembangunan jalan tol sepanjang 984km selama 2015-2019, pembangunan beberapa bandar udara, serta kestabilan pertumbuhan ekonomi Indonesia di tengah ketidakpastian ekonomi global merupakan contoh hasil kerja pemerintah dalam upaya percepatan pembangunan secara fisik. Namun demikian, kritikan justru ditujukan kepada aspekaspek yang tak kasat mata secara langsung, yakni aspek-aspek yang berkaitan dengan kesejahteraan dan kualitas pendudukan yang direpresentasikan melalui indeks pembangunan manusia yang dinilai sebagai salah satu indikator terciptanya pembangunan yang mendorong pertunbuhan ekonomi (Lilya Santika Dewi \& Sutrisna, 2014). Menurut Badan Pusat Statistik, indeks pembangunan manusia (IPM) menjelaskan bagaimana penduduk dapat mengakses hasil hasil pembangunan dalam memeroleh pendapatan, kesehatan, pendidikan, dan sebagainya. Banyak pihak menilai bahwa kesejahteraan rakyat seakan terkesampingkan, terutama perihal akses dan pemerataan pendidikan, meskipun sebenarnya indikator-indikator tersebut tidak dapat didikotomi dengan menganggap salah satu faktor lebih penting dibanding faktor lainnya.

Pendidikan dipandang sebagai ujung tombak dalam membangun negeri ("Human Development Report (HDR)," 2014). Namun, laporan-laporan yang menggambarkan kualitas pendidikan di Indonesia masih belum memuaskan. Misalnya angka putus sekolah yang tinggi, angka melek huruf yang rendah, hingga rata-rata lama sekolah yang masih jauh lebih rendah dibanding dengan negara-negara serumpun,katakanlah Malaysia, Singapura, dan Thailand. Di Indonesia sendiri, indeks pendidikan tertinggi ada pada provinsi DKI Jakarta sebagai Ibukota negara dengan rata-rata lama sekolah 11,05 tahun (data tahun 2018). Sementara Papua memiliki indeks pendidikan terendah dengan rata-rata lama sekolah 6,52 tahun. Melihat provinsi-provinsi lain, di pulau Jawa misalnya yang dianggap sebagai pusat sebagian besar aktivitas perekonomian nasional, ternyata indeks pendidikan provinsi-provinsi di pulau Jawa masih berada di bawah provinsi di pulau Sumatera, bahkan Maluku. Di pulau Jawa, Jawa Barat dan Jawa Timur menempati dua posisi terendah untuk indeks pendidikannya.

Hal yang menarik untuk dikaji adalah provinsi Jawa Barat yang sebagian wilayahnya berbatasan langsung dengan provinsi DKI Jakarta, namun memiliki ketimpangan indeks pendidikan dibandingkan dengan DKI Jakarta. Bahkan, sejak 7 tahun terakhir (2011 hingga 2018), rata-rata lama sekolah provinsi Jawa Barat selalu berada di bawah rata-rata lama sekolah secara nasional. Jawa barat sendiri merupakan provinsi dengan luas $35.378 \mathrm{~km}^{2}$ serta terdiri dari 9 kota dan 18 kabupaten. Banyaknya kabupaten yang dua kali lipat dari banyaknya kota menjadi pekerjaan rumah besar bagi pemerintah daerah untuk menjamin pemerataan hasil pembangunan ke kabupaten maupun kota. Fakta menunjukkan bahwa masih terdapat jarak yang cukup signifikan pada indeks pendidikan antara kabupaten dan kota di Jawa Barat. Dalam 7 tahun terakhir sejak 
2011 hingga 2018, indeks pendidikan di kabupaten di Jawa Barat sebesar 0,56 atau 56\%, sedangkan indeks pendidikan kota di Jawa Barat 0,69 atau 69\%. Angka ini dihitung berdasarkan angka harapan lama sekolah dan rata-rata lama sekolah. Selisih angka $13 \%$ ini memberikan indikasi bahwa belum meratanya hasil pembangunan pada sektor pendidikan di provinsi Jawa Barat, padahal penelitian terdahulu oleh Riani (2004) mengatakan bahwa sektor pendidikan menjadi penopang IPM di Jawa Barat.

Merespon kondisi yang telah dipaparkan di atas, maka studi ini bertujuan untuk melakukan perbandingan pemodelan faktor-faktor yang memengaruhi indeks pendidikan antara Kota dan Kabupaten yang ada di Provinsi Jawa Barat. Official statistics mengambil peran dalam hal ini, yakni meberikan informasi berupa data-data yang mendukung untuk melakukan pemodelan pada studi ini. Data yang dihimpun berupa data lintas waktu (2011-2018) dan data lintas daerah (kabupaten dan kota), sehingga berdasarkan karakteristik data yang diperoleh maka salah satu analisis yang dapat digunakan adalah analisis regresi data panel (Hsiao, 2014). Data panel adalah data yang terdiri dari kumpulan amatan terhadap suatu objek dalam suatu periode waktu (Gujarati, 2004) . Melalui data panel dapat diperoleh gambaran tentang perilaku suatu peubah pada beberapa individu selama periode waktu tertentu.

Peubah penjelas yang digunakan untuk menjelaskan indeks pendidikan dalam studi ini adalah indeks keparahan kemiskinan, jumlah penduduk miskin, laju pertumbuhan penduduk, dan angka harapan hidup. Variabel-variabel tersebut mewakili 3 aspek, di antaranya adalah aspek kemiskinan, kesehatan, dan kependudukan, sebagaimana studi terdahulu yang dilakukan oleh Berthalina (2014) tentang faktor-faktor yang memengaruhi IPM di Jawa Barat dengan menggunakan efek spasial yang mengakomodir korelasi maupun keragaman antar wilayah di Jawa Barat.

\section{METODE}

Studi ini menggunakan data sekunder yang didapatkan dari situs resmi dari Badan Pusat Statistik (BPS) provinsi Jawa Barat. Data yang digunakan berupa data tahunan yang terbagi ke dalam 17 kabupaten dan 9 kota di Jawa Tengah. Dalam hal ini, terdapat satu kabupaten yang tidak diikutsertakan dalam analisis, yaitu kabupaten trmuda di Jawa Barat, Pangandaran. Hal ini dikarenakan masih minimnya informasi terkait indeks yang diperlukan karena kabupaten Pangandaran baru berdiri pada tahun 2018. Peubah respon yang diamati pada penelitian ini adalah indeks pendidikan di Jawa Barat (IPD), sedangkan peubah penjelas yang diujikan adalah indeks keparahan kemiskinan (IKK), jumlah penduduk miskin (JPM), laju pertumbuhan penduduk (LPP), dan angka harapan hidup (AHP). Seluruh data dari masing-masing peubah diambil berdasarkan data tahun 2011 hingga tahun 2018 yang diambil dari data BPS.

Indeks pendidikan (IPD) merupakan suatu ukuran yang menjadi salah satu komponen penyusun indeks pembangunan manusia. Indeks pendidikan mengukur bagaimana kemudahan masyarakat dalam mengakses hasil pembangunan di bidang pendidikan (bps, 2018). Dua indikator utama yang menyusun IPD adalah rata-rata lama sekolah (RLS) dan angka harapan lama sekolah (HLS) (Mahendra et al., 2016)

Rata-rata lama sekolah (mean years of schooling) adalah jumlah tahun yang digunakan oleh penduduk dalam menjalani pendidikan formal. Penghitungan dilakukan pada penduduk yang berusia 25 tahun ke atas dimana diasumsikan seseorang yang telah berumur 25 tahun, maka proses pendidikannya telah berakhir. Perhitungan rata-rata lama sekolah pada usia 25 tahun keatas juga mengikuti standar internasional yang digunakan oleh UNDP. Dalam perhitungan ratarata lama sekolah, penduduk yang tamat SD diperhitungkan lama sekolah selama 6 tahun, tamat SMP diperhitungkan lama sekolah selama 9 tahun, tamat SMA diperhitungkan lama sekolah selama 12 tahun tanpa memperhitungkan apakah pernah tinggal kelas atau tidak. Rumus yang digunakan sebagai berikut.

$R L S=\frac{1}{n} \times \sum_{i=1}^{n} x_{i}$

indeks $R L S=\frac{R L S-R L S_{\min }}{R L S_{\text {maks }}-R L S_{\min }}$ 
dimana:

RLS = rata-rata lama sekolah

$\mathrm{x}_{\mathrm{i}} \quad=$ lama sekolah penduduk ke- $i$ yang berusia minimal 25 tahun

$\mathrm{n} \quad=$ banyaknya penduduk berusia 25 tahun ke atas

Harapan lama sekolah (HLS)/Expected years of schooling (EYS) adalah lamanya sekolah (dalam tahun) yang diharapkan akan dirasakan oleh anak pada umur tertentu di masa mendatang. Asusmsi Harapan lama sekolah yaitu kemungkinan anak tersebut akan tetap bersekolah pada umur-umur berikutnya sama dengan rasio penduduk yang bersekolah per jumlah penduduk untuk umur yang sama saat ini. Tujuan Harapan Lama Sekolah adalah untuk mengetahui kondisi pembangunan sistem pendidikan di berbagai jenjang yang ditunjukkan dalam bentuk lamanya pendidikan (dalam tahun) yang diharapkan dapat dicapai setiap anak. Rumus yang digunakan untuk mengukur HLS adalah sebagai berikut.

$H L S_{a}^{t}=F K \times \sum_{i=a}^{n} \frac{E_{i}^{t}}{P_{i}^{t}}$

indeks $H L S=\frac{H L S-H L S_{\min }}{H L S_{m a k s}-H L S_{\min }}$

dimana:

$H L S_{a}^{t}=$ Harapan lama sekolah di umur ke- $a$ dan tahun ke- $t$

$E_{i}^{t} \quad=$ jumlah penduduk usia $i$ yang bersekolah pada tahun $t$

$P_{i}^{t} \quad=$ jumlah penduduk usia $i$ pada tahun ke $t$

$I \quad=$ Usia $(a, a+1, \ldots, n)$

FK = Faktor koreksi (bagi penduduk yang mengenyam pendidikan di pesantren)

Berdasarkan dua indikator di atas, maka formulasi indeks pendidikan dihitung sebagai berikut.

Indeks Pendidikan $=\frac{I_{H L S}+I_{R L S}}{2}$

Analisis data dalam studi ini menggunakan analisis regresi data panel. Data panel merupakan gabungan antara data cross-section dengan time series (Baltagi, 2013). Pada data panel individu yang sama diukur selama periode waktu. Dapat dikatakan bahwa data panel memiliki dimensi ruang dan waktu. Analisis regresi merupakan analisis yang digunakan untuk melihat hubungan satu peubah dengan lainnya. Model umum regresi data panel adalah sebagai berikut.

$y_{i t}=a+\boldsymbol{X}^{\prime}{ }_{i t} \boldsymbol{\beta}+u_{i t}$

dimana:

$y_{i t} \quad=$ peubah respon untuk individu ke-i dan waktu ke-t

$\alpha \quad=$ komponen konstanta

$X_{i t}^{\prime} \quad=$ vektor peubah penjelas

$\beta \quad=$ koefisien peubah penjelas

$u_{i t} \quad=$ Komponen sisaan

Berdasarkan komponen sisaannya, model data panel terdiri dari model komponen sisaan satu arah dan model komponen sisaan dua arah. Model yang hanya ada pengaruh spesifik individu atau pengaruh spesifik waktu saja dalam modelnya disebut model komponen sisaan satu arah. Sementara model data panel yang terdiri dari kedua pengaruh spesifik tersebut maka model ini dikenal dengan model komponen sisaan dua arah. Selanjutnya, apabila ditinjau melalui metode pendugaan parameternya, menurut (Gujarati, 2004) terdapat tiga pendekatan model yang biasa digunakan untuk pendugaan parameter pada regresi data panel, yaitu model gabungan, model pengaruh tetap, dan model pengaruh acak. 
Komponen sisaan dalam regresi data panel terdiri dari komponen umum dan komponen spesifik. Komponen sisaan umum yaitu sisaan untuk individu ke- $i$ dan waktu ke- $t$ sedangkan komponen sisaan spesifik terdiri dari pengaruh spesifik individu yang tidak teramati dan pengaruh spesifik waktu yang tidak teramati (Baltagi, 2013). Komponen sisaan dalam model regresi data panel dapat dituliskan sebagai berikut.

$u_{i t}=\mu_{i}+\lambda_{t}+\varepsilon_{i t}$

dimana:

$u_{i t} \quad=$ komponen sisaan untuk individu ke- i pada waktu ke- $\mathrm{t}$

$\mu_{i} \quad=$ pengaruh spesifik individu ke-i

$\lambda_{t} \quad=$ pengaruh spesifik waktu ke-t

$\varepsilon_{i t} \quad=$ sisaan untuk individu ke-i waktu ke-t.

\section{Model Gabungan, Model Tetap, dan Model Acak}

Model gabungan (pooled model) dapat dikatakn sebagai model yang paling sederhana dalam regresi data panel. Pada model gabungan tidak memerhatikan pengaruh spesifik individu $\left(\mu_{i}\right)$ maupun pengaruh spesifik waktu $\left(\lambda_{t}\right)$ di dalam model, sehingga diasumsikan bahwa seluruh koefisien regresi, baik intersep maupun slope adalah konstan antar individu dan waktu. Persamaan model yang digunakan mengikuti bentuk regresi linear dengan komponen sisaan $u_{i t}$ yang hanya berasal dari komponen sisaan pendugaan $\left(\varepsilon_{i t}\right)$. Begitupun untuk metode pendugaan parameternya mengikuti pendugaan parameter seperti pada model regresi linier biasa yaitu menggunakan metode kuadrat terkecil (MKT), yaitu dengan menggabungkan data lintas individu serta data deret waktu menjadi satu kesatuan data yang utuh (Gujarati, 2004). Persamaan model gabungan dapat dituliskan sebagai berikut.

$y_{i t}=\alpha+\beta_{1} x_{1, i t}+\beta_{2} x_{2, i t}+\cdots+\beta_{k} x_{k, i t}+\varepsilon_{i t}$

Model pengaruh tetap didasarkan pada asumsi bahwa intersep antar individu dan waktu tidaklah sama, tetapi koefisien regresi konstan untuk semua individu dan waktu. Di samping itu, pada model pengaruh tetap diasumsikan terdapat korelasi antara pengaruh spesifik individu $\left(\mu_{i}\right)$ dan pengaruh spesifik waktu $\left(\lambda_{t}\right)$ dengan peubah bebas. Asumsi ini membuat pengaruh spesifik individu dan pengaruh spesifik waktu menjadi bagian dari intersep (Baltagi 2008). Persamaan model pengaruh tetap dapat dituliskan sebagai berikut.

Kompoten sisaan satu arah:

$y_{i t}=\alpha+\mu_{i}+\beta_{1} x_{1, i t}+\beta_{2} x_{2, i t}+\cdots+\beta_{k} x_{k, i t}+\varepsilon_{i t}$

atau

$y_{i t}=\alpha+\lambda_{t}+\beta_{1} x_{1, i t}+\beta_{2} x_{2, i t}+\cdots+\beta_{k} x_{k, i t}+\varepsilon_{i t}$

Kompoten sisaan dua arah:

$y_{i t}=\alpha+\mu_{i}+\lambda_{t}+\beta_{1} x_{1, i t}+\beta_{2} x_{2, i t}+\cdots+\beta_{k} x_{k, i t}+\varepsilon_{i t}$

dengan $\mu_{i}$ dan $\lambda_{t}$ berturut-turut merupakan pengaruh spesifik waktu dan pengaruh spesifik individu, serta $\sum_{i=1}^{N} \mu_{i}=0$ dan $\sum_{t=1}^{N} \lambda_{t}=0$. Perbedaan intersep antar individu dan waktu disebabkan oleh perbedaan karakteristik antar individu dan waktu, sehingga pendugaan parameter dengan kondisi tersebut perlu diakomodir menggunakan metode Peubah Boneka Kuadrat Terkecil (PBKT).

Terrakhir, model pengaruh acak mengasumsikan tidak adanya korelasi antara pengaruh spesifik individu $\left(\mu_{i}\right)$ dan pengaruh spesifik waktu $\left(\lambda_{t}\right)$ terhadap peubah bebas. Asumsi ini membuat komponen sisaan dari pengaruh spesifik individu dan pengaruh spesifik waktu dimasukan kedalam komponen sisaan. Persamaan model pengaruh acak dapat dituliskan sebagai berikut.

Kompoten sisaan satu arah:

$y_{i t}=\alpha+\beta_{1} x_{1, i t}+\beta_{2} x_{2, i t}+\cdots+\beta_{k} x_{k, i t}+\mu_{i}+\varepsilon_{i t}$ 
atau

$y_{i t}=\alpha+\beta_{1} x_{1, i t}+\beta_{2} x_{2, i t}+\cdots+\beta_{k} x_{k, i t}+\lambda_{t}+\varepsilon_{i t}$

Kompoten sisaan dua arah:

$y_{i t}=\alpha+\beta_{1} x_{1, i t}+\beta_{2} x_{2, i t}+\cdots+\beta_{k} x_{k, i t}+\mu_{i}+\lambda_{t}+\varepsilon_{i t}$

dimana:

$\mu_{i} \sim N\left(0, \sigma_{i}^{2}\right)$ dan $\lambda_{t} \sim N\left(0, \sigma_{t}^{2}\right)$ serta $\operatorname{cov}\left(\mu_{i}, x_{i t}\right)=0$ serta $\operatorname{cov}\left(\lambda_{t}, x_{i t}\right)=0$

Pendugaan parameter model pengaruh acak menggunakan Generalized Least Square.

Adapun tahapan-tahapan dalam studi ini meliputi :

1. Eksplorasi data untuk melihat gambaran umum indeks pendidikan provinsi Jawa Barat dalam kurun waktu 2011-2018

2. Melakukan pendugaan parameter model gabungan dengan metode kuadrat terkecil

3. Melakukan pendugaan parameter model pengaruh tetap individu dan parameter model pengaruh tetap waktu dengan metode Peubah Boneka Kuadrat Terkecil (PBKT).

4. Melakukan uji Chow untuk melihat ada atau tidaknya pengaruh spesifik individu dan pengaruh spesifik waktu. Apabila hasil pengujian menyatakan adanya pengaruh spesifik individu dan/atau pengaruh spesifik waktu (model pengaruh tetap model yang terpilih), lanjut pada tahapan (5), namun apabila tidak ada pengaruh spesifik individu dan pengaruh spesifik waktu (model gabungan yang terpilih), tahapan analisis langsung ke tahap (7)

5. Melakukan pendugaan parameter model pengaruh acak dengan metode Generalized Least Square (GLS).

6. Melakukan pengujian pemilihan model yang tepat antara model pengaruh tetap dengan model pengaruh acak menggunakan uji Hausman

7. Melakukan pengujian asumsi regresi data panel dan penanganan terhadap asumsi yang tidak terpenuhi

8. Melakukan interprtasi model

\section{HASIL DAN PEMBAHASAN}

\section{Eksploasi Data}

Jawa Barat merupakan provinsi terluas kedua di Pulau Jawa setelah Jawa Timur. Menariknya, provinsi Jawa Barat menempati posisi kedua terendah terkait indeks pendidikan, setelah Jawa Timur juga. Ekplorasi awal terhadap dilakukan guna melihat bagaimana pergerakan indeks pendidikan di Jawa Barat dari tahun ke tahun sejak 2011 hingga 2018 serta melihat bagaimana korelasi antara. Berikut grafik pergerakan IPD provinsi Jawa Barat (2011-2018) yang dikelompokkan menurut kabupaten dan kota.
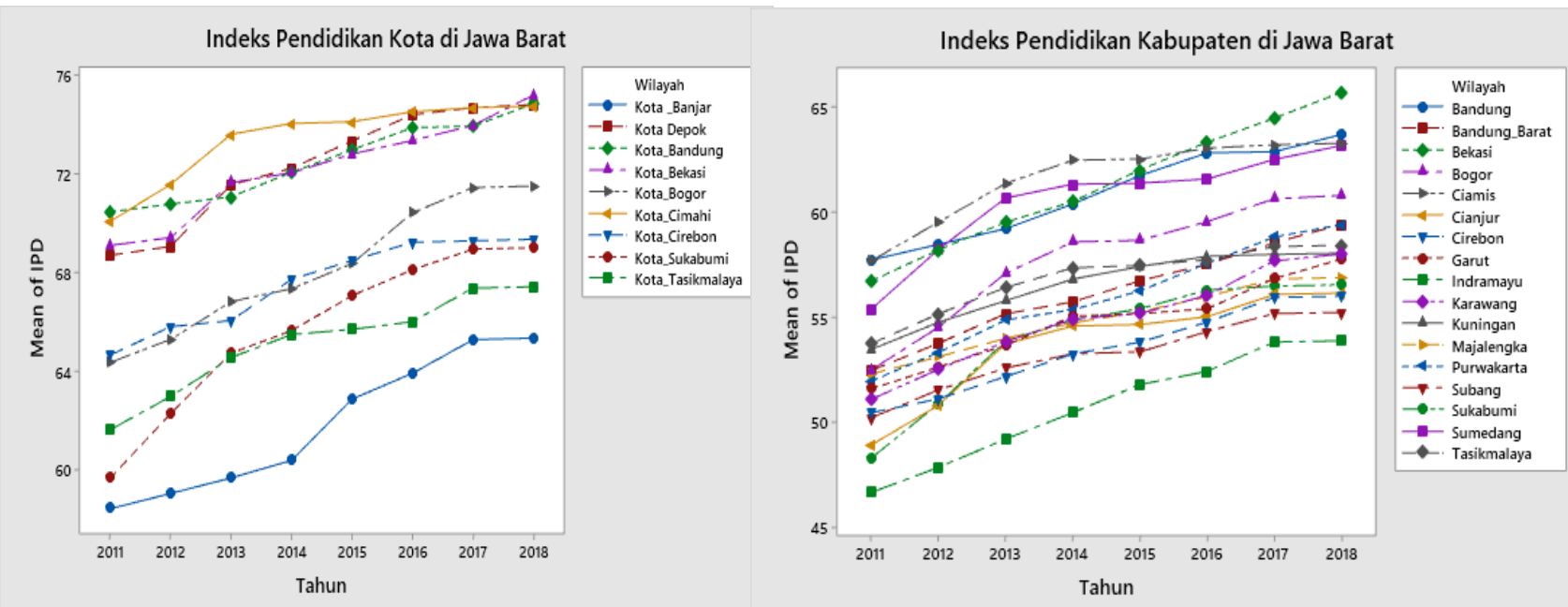

Gambar 1. Grafik Perkembangan Indeks Pendidikan Kota dan Kabupaten di Jawa Barat. 
Terlihat jelas bahwa anatara kabupaten dan kota memiliki perbedaan karakteristik yang signifikan dengan perbedaan skor indeks pendidikan antar keduanya. Bahkan, di wilayah antar kota dan kabupaten sendiri masih terlihat perbedaan karakteristik yang memungkinkan tiap kota maupun kabupaten dapat memiliki model yang berbeda. Misalnya saja pada kota Cimahi, Depok, Bandung, dan Bekasi cenderung terpisah dari kota yang lain. Sama halnya untuk kabupaten Bandung, Sumedang, Ciamis, dan Bekasi untuk wilayah kabupaten. Perbedaan karakteristik dan letak geografis menjadi faktor yang paling memungkinkan terjadinya perbedaan ini.

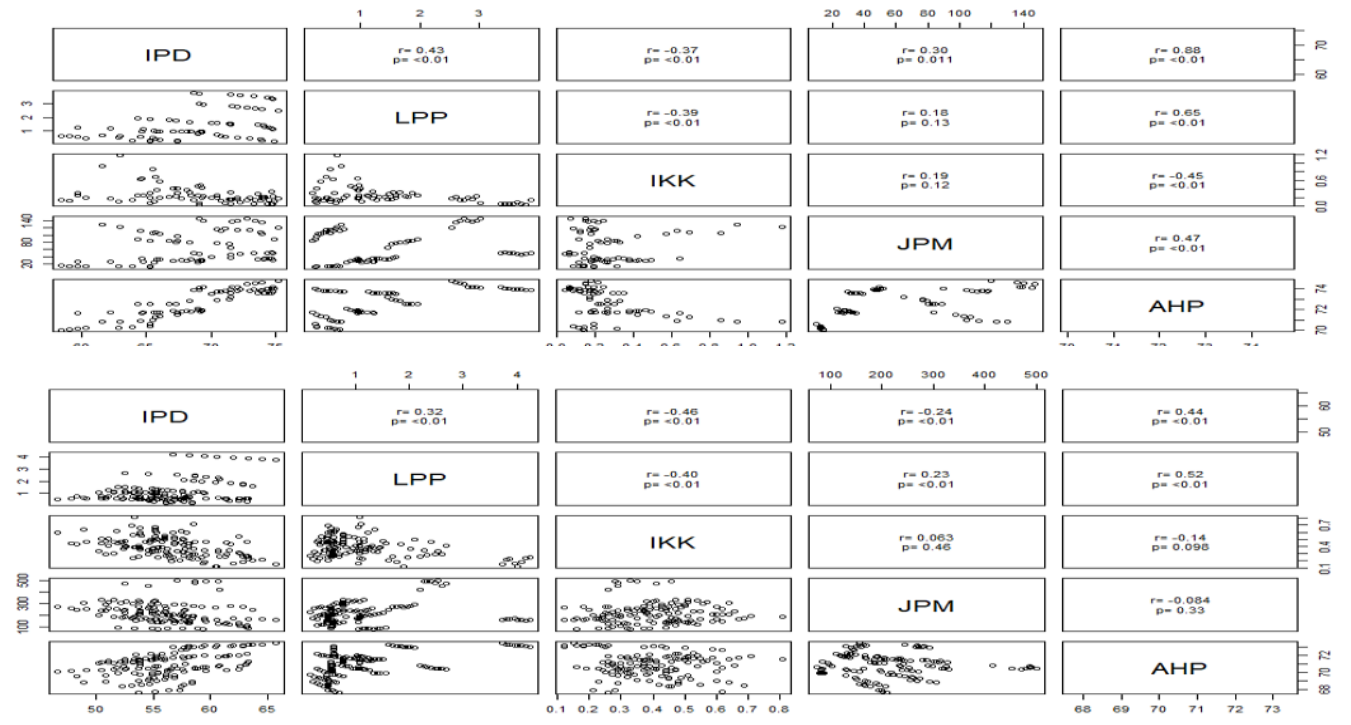

Gambar 2. Korelasi antara peubah respon (IPD) dengan peubah penjelas (lainnya) pada kota (gambar atas) dan kabupaten (gambar bawah) di Jawa Barat

Berdasarkan gambar 1 di atas, terlihat bahwa baik di wilayah kota maupun kabupaten, indeks pendidikan cenderung mengalami peningkatan setiap tahunnya. Di wilayah kota, Cimahi memiliki indeks pendidikan yang tertinggi sejak 2011, meskipun pada 2018 terlihat bahwa indeks pendidikan kota Cimahi, Depok, Bandung, dan Bekasi hampir berada di titik yang sama. Indeks pendidikan terendah untuk wilayah kota adalah kota Banjar. Sementara di wiliayah kabupaten, pada tahun 2018 terlihat bahwa kabupaten Bekasi memiliki indeks pendidikan tertinggi, sedangkan yang terendah adalah kabupaten Indramayu.

\section{Spesifikasi Model}

Spesifikiasi model dilakukan untuk melakukan pendugaan parameter model regresi data panel yang sesuai dengan karakteristik data yang dianalisis. Prosedur ini diawali dengan memodelkan data dengan model gabungan, yakni memperlihatkan data individu maupun waktu menjadi satu kesatuan tanpa memerhatikan pengaruh spesifiki dari keduanya. Hasilnya sebagai berikut.

Tabel 1. Hasil pendugaan parameter model gabungan

\begin{tabular}{lcccc}
\hline \multirow{2}{*}{ peubah } & \multicolumn{3}{c}{ Model Pengaruh Gabungan } \\
\cline { 2 - 5 } & \multicolumn{2}{c}{ Wilayah Kota } & \multicolumn{2}{c}{ Wilayah Kabupaten } \\
\cline { 2 - 5 } & Koefisien & P value & Koefisien & Pvalue \\
\hline Intersep & $-223,08$ & $0 *$ & $-7,42$ & 0,64 \\
IKK & 2,67 & $0,04^{*}$ & $-11,006$ & $0^{*}$ \\
LPP & $-1,2$ & $0,00002^{*}$ & 0,074 & 0,847 \\
JPM & $-0,0268$ & $0.0001^{*}$ & $-0,0077$ & $0,01^{*}$ \\
AHP & 4,05 & $0 *$ & 0,983 & $0,00003^{*}$ \\
\hline Adj R-sq & \multicolumn{2}{c}{0,83693} & \multicolumn{2}{c}{0,38775} \\
P-value & \multicolumn{2}{c}{$0 *$} & \multicolumn{3}{c}{$0 *$} \\
\hline
\end{tabular}


Berdasarkan hasil analisis di atas, terlihat bahwa pada model gabungan untuk wilayah kota, seluruh variabel penjelas tampak signifikan dalam menerangkan variabel indeks pendidikan dengan $\mathrm{R}^{2}$ sebesar 83,69\%. Artinya sebesar 83,69\% keragaman dari indeks pendidikan diterangkan oleh variabel IKK, LPP, JMP, dan AHP, sedangkan sisanya diterangkan oleh faktor lain. Pada level kabupaten, variabel penjelas yang signifikan hanyalah IKK, JPM, dan AHP dengan $\mathrm{R}^{2}$ sebesar 38,77\%. Aritinya, keragaman dari indeks pendidikan di kabupaten di Jawa Barat diterangkan oleh variabel-variabel yang signifikan sebesar 38,775\%, sementara sisanya diterangkan oleh faktor lain.

Setelah mendapatkan pendugaan parameter model regresi data panel dengan pendekatan model gabungan, dilanjutkan dengan pendugaan dengan model pengaruh tetap. Pengaruh tetap dianalisis melalui dua pendekatan, yakni dengan melihat efek waktu dan efek individu. Hasil pendugaan parameter untuk model pengaruh tetap disajikan pada tabel 2 .

Tabel 2. Hasil pendugaan parameter model tetap pengaruh individu dan waktu

\begin{tabular}{ccccccccc}
\hline \multirow{2}{*}{ Peubah } & \multicolumn{3}{c}{ Model tetap pengaruh individu } & \multicolumn{3}{c}{ Model tetap pengaruh waktu } \\
\cline { 2 - 9 } & \multicolumn{2}{c}{ Wilayah Kota } & \multicolumn{2}{c}{ Wilayah Kabupaten } & \multicolumn{2}{c}{ Wilayah Kota } & \multicolumn{2}{c}{ Wilayah Kabupaten } \\
\cline { 2 - 9 } & Koefisien & P value & Koefisien & Pvalue & Koefisien & P value & Koefisien & Pvalue \\
\hline Intersep & 207,08 & 0,001 & $-11,05$ & 0,00005 & $-211,05$ & $0,0004^{*}$ & $-7,87$ & $0 *$ \\
IKK & 0,125 & 0,92 & 0,7348 & 0,48 & 3,298 & $0,00005^{*}$ & $-9,03$ & $0,000004^{*}$ \\
LPP & $-11,85$ & $0 *$ & $-10,085$ & $0^{*}$ & $-0,655$ & $0,00013^{*}$ & 0,754 & $0,026^{*}$ \\
JPM & 0,031 & 0,277 & $-0,012$ & 0,09 & $-0,02$ & $0,000001^{*}$ & $-0,007$ & $0,0029^{*}$ \\
AHP & 2,488 & 0,09 & 2,755 & 0 & 3,61 & $0^{*}$ & 0,552 & $0,0058^{*}$ \\
\hline Adj R-sq & 0,77915 & 0,76239 & 0,93205 & 0,37955 \\
P-value & 0,087 & 0,128 & $0 *$ & 0 & $0 *$ \\
\hline
\end{tabular}

Berdasarkan informasi dari tabel 2, terlihat bahwa untuk model pengaruh tetap hanya variabel LPP saja yang signifikan dengan $\mathrm{R}^{2}$ sebesar $77,9 \%$, sedangkan pada model tetap pengaruh waktu memiliki $\mathrm{R}^{2}$ sebesar $93,2 \%$ dengan seluruh variabel penjelas signifikan. Sementara untuk wilayah kabupaten, pada model tetappengaruh individu memiliki $\mathrm{R}^{2}$ sebesar $76,2 \%$ dengan variabel penjelas yang signifikan hanya variabel LPP saja, sedangkan pada model tetap pengaruh waktu, seluruh variabel penjelas signifikan berpengaruh terhadap respon, namun $\mathrm{R}^{2}$ hanya sebesar $37,9 \%$. Melalui hasil analisis ini dapat diserap informasi mengenai model mana yang dapat menjelaskan persoalan data panel baik untuk level kota maupun kabupaten. Nilai p-value pada tabel 2 menunjukkan signifikansi dari model yang berkaitan dari hasil uji Chow. Pada hasil di atas, terlihat bahwa baik pada level kota maupun kabupaten, model yang sesuai adalah model tetap dengan efek waktu.

Tabel 3. Hasil pendugaan parameter model acak pengaruh waktu

\begin{tabular}{ccccc}
\hline \multirow{2}{*}{ Peubah } & \multicolumn{3}{c}{ Model acak dengan efek waktu } \\
\cline { 2 - 5 } & \multicolumn{2}{c}{ Wilayah Kota } & \multicolumn{2}{c}{ Wilayah Kabupaten } \\
\cline { 2 - 5 } & Koefisien & P value & Koefisien & Pvalue \\
\hline Intersep & $-217,39$ & $0 *$ & $-7,429$ & 0,645 \\
IKK & 2,7947 & 0,02 & $-11,006$ & $0,0000007^{*}$ \\
LPP & $-1,105$ & $0,00001^{*}$ & $-0,074$ & 0,847 \\
JPM & $-0,0256$ & $0,00003^{*}$ & $-0,007$ & $0,01^{*}$ \\
AHP & 3,974 & $0 *$ & 0,9833 & $0,00001^{*}$ \\
\hline Adj R-sq & \multicolumn{3}{c}{0,85204} & \multicolumn{2}{c}{0,38775} \\
P-value & \multicolumn{2}{c}{$0 *$} & \multicolumn{2}{c}{$0 *$} \\
\hline
\end{tabular}

Tahapan analisis selanjutnya adalah pendugaan parameter dengan model pengaruh acak. Hasil pendugaan pengaruh acak ini akan dibandingkan dengan model tetap pengaruh individu 
yang telah diperoleh sebelumnya. Perbandingan dilakukan melalui uji Hausman. Tabel 3 menjelaskan hasil analisis mengenai model pengaruh acak dengan efek waktu. Model pengaruh acak dengan efek individu tidak dilakukan analisis karena berdasarkan uji Chow sebelumnya menghasilkan efek atau pengaruh waktu saja. Hasil analisa tabel 3 menunjukkan bahwa nilai pvalue kurang dari 0,05 untuk kota maupun kabupaten. Artinya, keputusan pengujian hipotesis untuk uji Hausman adalah tolak $\mathrm{H}_{0}$ untuk kedua level wilayah. Berdasarkan kriteria spesifikasi model, maka model yang terbaik untuk memodelkan permasalah indeks pendidikan di Jawa Barat adalah model pengaruh tetap dengan efek waktu.

Terpilihnya model pengaruh tetap dengan efek waktu menandakan bahwa adanya korelasi antara pengaruh spesifik waktu $\lambda_{t}$ dan peubah bebas yang signifikan. Melalui model pengaruh tetap dengan efek waktu diperoleh persamaan yang menunjukkan karakteristik masing-masing wilayah, baik kota maupun kabupaten terhadap indeks pendidikan. Berikut ini adalah dugaan model pengaruh tetap individu untuk indeks pendidikan kota dan kabupaten di Jawa Barat yang diperoleh:

$\widehat{I P D}_{\text {kota }}=-211,05+\lambda_{t}+3,298 I K K-0,655 L P P-0,02 J P M+3,61 A H P$

$\widehat{I P D}_{\text {kabupaten }}=-7,87+\lambda_{t}-9,03 I K K+0,754 L P P-0,007 J P M+0,552 A H P$

dengan $\lambda_{t}$ merupakan besarnya pengaruh spesifik waktu ke-i. Pengaruh spesifik waktu setiap wilayah, baik kota maupun kabupaten dapat dilihat pada tabel berikut.

Tabel 4. Pengaruh Spesifik Waktu untuk Model Pengaruh Tetap bagi Kota dan Kabupaten

\begin{tabular}{ccc}
\hline Tahun & Pengaruh Waktu untuk Kota & Pengaruh Waktu untuk kabupaten \\
\hline 2011 & $-195,06$ & 18,176 \\
2012 & $-194,28$ & 19,479 \\
2013 & $-192,74$ & 20,689 \\
2014 & $-192,08$ & 21,205 \\
2015 & $-191,61$ & 22,93 \\
2016 & $-190,95$ & 22,879 \\
2017 & $-190,58$ & 23,821 \\
2018 & $-190,83$ & 23,303 \\
\hline
\end{tabular}

\section{Interpretasi Model}

Model regresi data panel yang sesuai untuk memodelkan indeks pendidikan di level kota adalah model pengaruh tetap dengan efek waktu yang menunjukkan bahwa terdapat korelasi antara pengaruh spesifik waktu dengan peubah-peubah penjelas yang signifikan, dalam hal ini seluruh peubah penjelas secara signifikan menjelaskan indeks pendidikan di wilayah kota, yakni indeks keparahan kemiskinan, laju pertumbuhan pendudukn, jumlah penduduk miskin, dan angka harapan hidup. Sama halnya dengan level kota, hasil analisis pada level kabupaten juga menunjukkan bahwa model yang sesuai untuk menggambarkan indeks pendidikan adalah model pengaruh tetap dengan efek waktu. Begitupun perihal peubah penjelas, bahwa seluruh peubah penjelas secara signifikan menjelaskan indeks pendidikan di tingkat kabupaten.

Pengaruh spesifik waktu yang diperoleh untuk model ini menggambarkan karakteristik dari indeks pendidikan di kota maupun kabupaten di Jawa Barat setiap tahunnya dengn besaran pengaruh spesifik waktu untuk masing-masing tahun dapat diperhatikan pada tabel 4. Perbedaan besaran pengaruh spesifik baik untuk wilayah kota maupun kabupaten dapat diinterpretasikan salah satunya terkait pergantian pemangku jabatan di masing-masing daerah yang mengakibakan pada perbedaan kebijakan. Sebab, dalam kurun waktu tahun 2011 hingga 2018 terdapat daerahdaerah yang mengalami dua sampai tiga kali pergantian pemimpin daerah. Seperti dapat dilihat pada tabel 2, peubah penjelas yang paling signifikan untuk level kota adalah angka harapan hidup, sedangkan untuk level kabupaten adalah jumlah penduudk miskin. Kondisi ini menggambarkan perbedaan karakteristik antara level kabupaten dan level kota. Perbedaan karakteristik ini dapat 
disebabkan oleh perbedaan letak geografis, jumlah penduduk, hingga tingkat kesejahteraan warganya di masing-masing wilayah, baik kota maupun kabupaten (Suradi, 2007)

Ditinjau dari koefisien determinasi $\left(R^{2}\right)$, untuk level kota diperleh $R^{2}$ sebesar 93,2\%. Artinya sebagian besar keragaman dari indeks pendidikan di kota di Jawa Barat diterangkan oleh IKK, JPM, LPP, dan AHP. Sedangkan untuk level kabupaten diperoleh $\mathrm{R}^{2}$ sebesar $37,9 \%$. Hal ini menunjukkan bahwa sebagian besar keragaman dari indeks pendidikan di kabupaten di Jawa Barat diterangkan oleh faktor di luar yang diamati pada studi ini. Hal ini menunjukkan perbedaan karakteristik antara wilayah kota dan kabupaten. Untuk wilayah kabupaten, masih perlu ditinjau kembali faktor-faktor yang memengaruhi indeks pendidikan di luar peubah penjelas yang digunakan padastudi ini. Sementara di level kota, sangat penting untuk memerhatikan keseimbangan antara faktor-faktor penjelas dalam implementasi regulasi pemerintahan, sebab melihat tingginya koefisien determinasi dari model untuk wilayah kota.

\section{KESIMPULAN}

Kota Depok, Bandung, Bogor, dan Bekasi menjadi kota-kota dengan indeks pendidikan tertinggi di Jawa Barat dan cenderung mengelompok dibandingkan denga kota-kota lain. Indikasi awal mengenai hal ini adalah nampaknya terdapat efek individu pada pemodelan untuk data di level kota. Namun, hasil analisis menunjukkan bahwa model regresi data panel yang sesuai untuk menggambarkan kasus di level kota adalah model pengaruh tetap dengan efek waktu dengan $\mathrm{R}^{2}$ sebesar 93,2\%. Artinya variabel-variabel penjelas yang terlibat daam studi ini menjelaskan keragaman indeks pendidikan di kota-kota di Jawa Barat sebesar 93,2\%. Demikian pula halnya untuk level kabupaten, model yang sesuai juga model pengaruh tetap dengan efek waktu dan $\mathrm{R}^{2}$ sebesar 37,9\%. Artinya keragaman dari indeks pendidikan di kabupaten di Jawa Barat diterangkan oleh peubah-peubah penjelas yang digunakan pada studi ini. Sementara sisanya 62,1\% diterangkan oleh faktor lain. Efek waktu dalam kedua model menggambarkan bahwa terdapat korelasi spesifik antara waktu dengan peubah-peubah penjelas yang digunakan.

\section{DAFTAR PUSTAKA}

Baltagi, B. H. (2013). Econometric Analysis of Panel Data - Fifth Edition. In John Wiley \& Sons, 2013.

Berthalina, H. (2014). Identifikasi faktor-faktor yang berpengaruh terhadap indeks pembangunan manusia provinsi jawa barat dengan pendekatan regresi spasial. Skripsi Institut Pertanian Bogor. $21 \mathrm{hlm}$

BPS. (2018). buku indeks pembangunna manusia. Indeks Pembangunan.

Gujarati, D. N. (2004). Basic Econometrics 4th Edition. In Tata McGraw-Hill. https://doi.org/10.1126/science.1186874

Hsiao, C. (2014). Analysis of panel data: Third edition. In Analysis of Panel Data: Third Edition. https://doi.org/10.1017/CBO9781139839327

Human Development Report (HDR). (2014). In Encyclopedia of Quality of Life and Well-Being Research. https://doi.org/10.1007/978-94-007-0753-5_101876

Lilya Santika Dewi, N., \& Sutrisna, I. (2014). PENGARUH KOMPONEN INDEKS PEMBANGUNAN MANUSIA TERHADAP PERTUMBUHAN EKONOMI PROVINSI BALI. E-Jurnal Ekonomi Pembangunan Universitas Udayana.

Mahendra, R., Fariyanti, A., \& Falatehan, A. F. (2016). STRATEGI PENINGKATAN INDEKS PENDIDIKAN MELALUI ALOKASI BELANJA PEMERINTAH DAERAH BIDANG PENDIDIKAN DI PROVINSI JAWA TIMUR. Jurnal Manajemen Pembangunan Daerah. https://doi.org/10.29244/jurnal_mpd.v8i2.24823

Riani, W. (2004). Pembangunan Pendidikan sebagai Motor Penggerak IPM Jawa Barat. Mimbar: Jurnal Sosial Dan Pembangunan.

Setiawan, M. B., \& Hakim, A. (2008). Indeks Pembangunan Manusia Manusia. Jurnal Economia, 9(1), 18-26.

Suradi. (2007). Pembangunan Manusia, Kemiskinan, dan Kesejahteraan Sosial (Kajian tentang Kebijakan Pembangunan Kesejahteraan Sosial di Nusa Tenggara Barat). Penelitian Dan Pengembangan Kesejahteraan Sosial. 